\title{
HYDROXYPROLINE IN THE ALLANTOIC FLUID OF THE MARE
}

\author{
S. KRVAVICA AND T. MARTINĞIC \\ Department of Pathological Physiology, School of Veterinary Medicine, University, \\ Zagreb, Tugoslavia
}

(Received 28th Fanuary 1969, revised 5th August 1970)

The occurrence of free amino acids in the amniotic and allantoic fluid of the cow and sow has recently been reported (Martincić, Herak \& Krvavica, 1969). In this study, the results obtained with the mare's allantoic fluid are recorded and show that substantial quantities of glutamic acid, glycine, alanine and proline and, in addition, a surprisingly large amount of hydroxyproline are present. This imino acid was also detected in the allantoic fluid of pregnant cows and sows, but in very much lower concentrations.

Animal organs and body fluids contain, on the whole, very little hydroxyproline. In the blood, Wiss (1949) found an average of $0.132 \mathrm{mg} / 100 \mathrm{ml}$ in rats, 0.171 in rabbits, and 0.290 in guinea-pigs; the quantities excreted daily in the urine were of the order of $10 \mu \mathrm{g}$. According to James (1955), there are about $100 \mu \mathrm{g}$ hydroxyproline in $100 \mathrm{ml}$ blood plasma; he also found $2.5 \mu \mathrm{g}$ in $0.5 \mathrm{ml}$ of packed white blood cells, but none in plasmolysed erythrocytes. Bates, McGowen \& Talmage (1962) found $0.080 \mu \mathrm{mol} / \mathrm{ml}$ of free hydroxyproline in plasma of normal rats and Prockop, Keiser \& Sjoerdsma (1962), studying two human subjects, found $1.2 \mu \mathrm{g}$ and $1.6 \mu \mathrm{g} / \mathrm{ml}$ of free hydroxyproline in plasma. Under controlled fasting conditions, the two subjects excreted about $1 \mu \mathrm{g}$ of free hydroxyproline/min. Lindstedt \& Prockop (1961) investigated the excretion of hydroxyproline in rats of varying ages and found that 3-week-old rats excreted $73 \mu \mathrm{g} / 24 \mathrm{hr}$ of free hydroxyproline, while 2-year-old rats excreted two to three times less. Jasin \& Ziff (1962) have also determined the free hydroxyproline in the urine of the rats and have found that $22.2 \mu \mathrm{g}$ of this imino acid is excreted/24 $\mathrm{hr}$. In the rat spleen, there is also a small amount hydroxyproline (Akerfeldt, 1955) and, in the rat liver, Wolf \& Berger (1958) found only $1.1 \mu \mathrm{g}$ in the whole organ; however, after oral administration of proline, there was $12.9 \mu \mathrm{g}$.

For the present study, the allantoic fluid was collected from three pregnant mares, which were all accident cases. Deproteinization was carried out with ethanol, and de-salting with the cation exchanger Zeo-karb 225 (resin particles less than $50 \mu$ ). The free amino acids were determined by two-dimensional paper chromatography (Dent, 1948), and hydroxyproline was located by means of ninhydrin, $p$-dimethylaminobenzaldehyde and izatin. Quantitative determination of free hydroxyproline was carried out using a modification of McFarlane's method (Neuman \& Logan, 1950). Analyses were also performed 
in foetal blood, liver and kidney, and in the mare's blood during advanced stages of pregnancy. For the determinations in the liver and kidney, 5-g quantities of tissue were homogenized with $50 \mathrm{ml}$ of $96 \%$ ethanol, the homogenates centrifuged for $15 \mathrm{~min}$ at $3000 \mathrm{rev} / \mathrm{min}$, and the clear supernatant solutions evaporated to dryness. The dry material was dissolved in $2 \mathrm{ml}$ isopropanol, and $0.1 \mathrm{ml}$ applied to Whatman filter paper No. 1; the subsequent steps were as described by Dent (1948).

Plate 1, Fig. 1 is a chromatogram obtained with the allantoic fluid of a 10-month-old foetus, and Pl. 1, Figs. 2 and 3 show the results obtained with the liver and kidney of the same foetus. The allantoic fluid contained glutamic acid, serine, glycine, threonine, alanine, lysine, hydroxyproline, proline and valine; Pl. 1, Fig. 1 shows also the spot due jointly to leucine, isoleucine, tryptophan, phenylalanine and methionine; the hydroxyproline spot is quite conspicuous. In the foetal kidney, glutamic acid can be seen to predominate; there was less hydroxyproline in the kidney than in the allantoic fluid, but much more than in the liver. Very little hydroxyproline was found to be present in the blood of the pregnant mares. However, the quantitative determination of hydroxyproline in the allantoic fluid from the three pregnant mares revealed the presence of 22,24 and $34 \mathrm{mg} / 100 \mathrm{ml}$, respectively. This is some 300 times more than Wiss (1949) encountered in rat blood. In the mare which contained $34 \mathrm{mg} / 100 \mathrm{ml}$ of hydroxyproline in the allantoic fluid, the total volume of that fluid in the allantoic sac was about 3 litres. The total content of hydroxyproline was, therefore, of the order of $1 \mathrm{~g}$. The occurrence of such unusually large quantities of hydroxyproline is probably due to a high rate of collagen turnover in the pregnant mare. Much higher quantities of free hydroxyproline in the allantoic fluid of the pregnant mare than in the allantoic fluid of the pregnant cow and sow favour this assumption.

\section{REFERENCES}

Akerfeldt, S. (1955) Studies on the spleen from rats fed with $\mathcal{N}, \mathcal{N}$-dimethyl-4-aminoazobenzene. Arkiv Kemi, 7, 355.

Bates, K. W., McGowen, J. \& TAlmage, V. R. (1962) Influence of the parathyroids on plasma hydroxyproline levels. Endocrinology, 71, 189.

DENT, C. E. (1948) A study of the behaviour of some sixty amino acids and other ninhydrin-reacting substances on phenol-collidin filter-paper chromatograms, with notes as to occurrence of some of them in biological fluids. Biochem. F. 43, 169.

JAmEs, W. D. (1955) A connective-tissue constituent in the scab formed over cutaneous wounds. 7. Path. Bact. 69, 33.

JASIN, H. E. \& ZIFP, M. (1962) Relationship between soluble collagen and urinary hydroxyproline in the lathyritic rat. Proc. Soc. exp. Biol. Med. 110, 837.

\section{EXPLANATION OF PLATE 1}

Chromatograms of free amino acids in the allantoic fluid of a 10-month-old horse foetus (Fig. 1), in the foetal kidney (Fig. 2), and in the foetal liver (Fig. 3). Key to the aminoacid spots in Fig. 1: 1, glutamic acid; 2, serine; 3, glycine; 4, threonine; 5 , alanine; 6 , lysine; 7, hydroxyproline; 8 , proline; 9 , valine; 10 , spot for leucine, isoleucine, tryptophan, phenylalanine and methionine. In Fig. 2 and Fig. 3: 1, aspartic acid; 2 , glutamic acid; 3 , serine; 4, glycine; 5 , alanine; 6 , hydroxyproline; 7 , arginine; 8 , proline; 9 , valine; 10 , spot for leucine, isoleucine, tryptophan, phenylalanine and methionine. 
PLATE 1

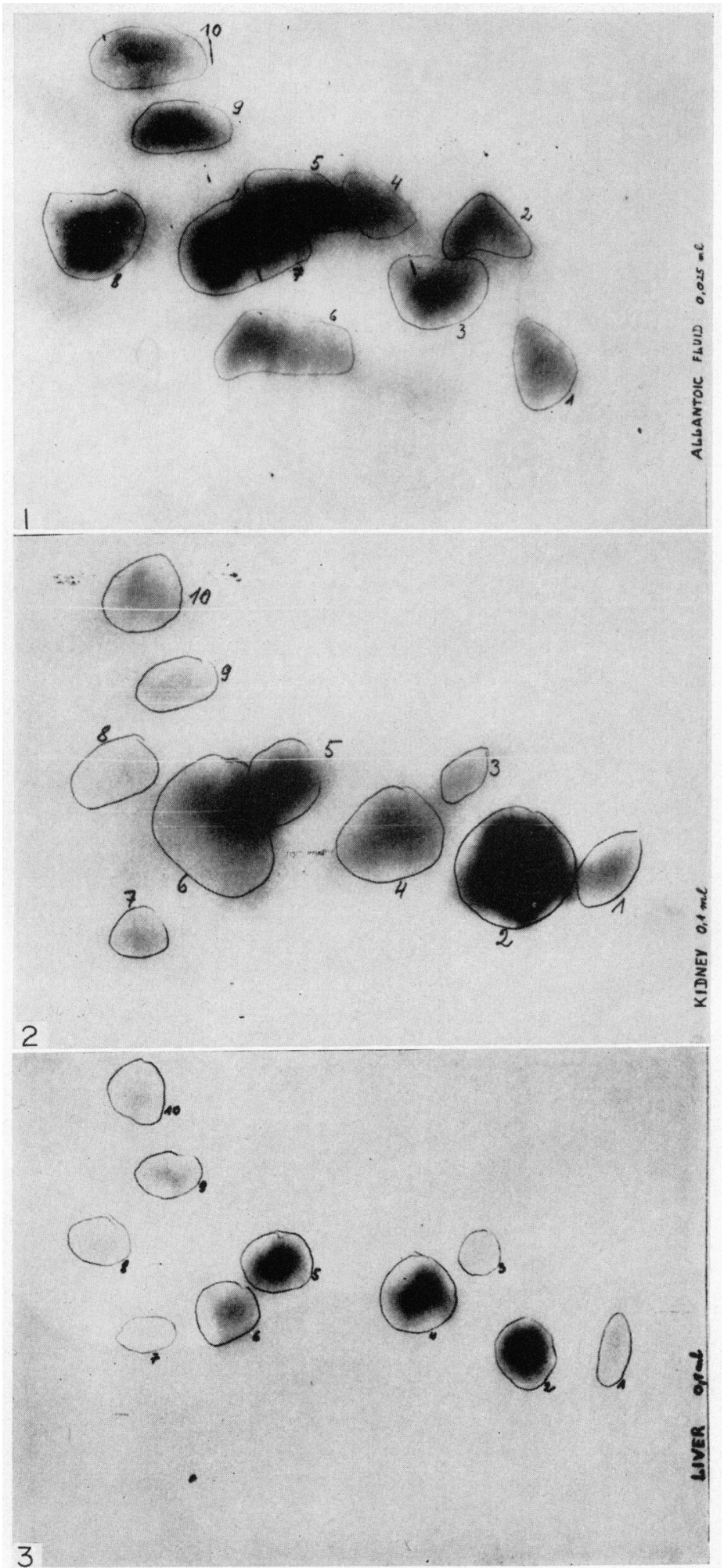


Lindstedt, S. \& PROckop, J. D. (1961) Isotopic studies on urinary hydroxyproline as evidence for rapidly catabolized forms of collagen in the young rat. J. biol. Chem. 236, 1399.

Martinčrć, T., Herax, M. \& Krvavica, S. (1969) Free amino acids in the foetal fluids of some domestic animals in the course of pregnancy. Vet. Arh. (in press).

Neuman, R. E. \& Logan, M. A. (1950) The determination of hydroxyproline. 7. biol. Chem. 184, 299.

Prockop, J. D., KeISER, R. H. \& SJOERDSMA, A. (1962) Gastrointestinal absorbtion and renal excretion of hydroxyproline peptides. Lancet, ii, 527.

WIss, O. (1949) Uber eine Mirkobestimmung des Oxyprolins in Blut und Harn; Beeinflussung des Oxyprolin-gehaltes durch Verabreichung von Prolin. Helv. chim. Acta, 32, 149.

WolF, G. \& BERGER, A. R. G. (1958) The metabolism of hydroxyproline in the intact rat. Incorporation of hydroxyproline into protein and urinary metabolites. F. biol. Chem. 230, 231. 